\title{
The Representation of Chivalry in The Knight's Tale
}

\author{
Jordi Sánchez Martí \\ Cornell University \\ js167@cornell.edu
}

\begin{abstract}
The purpose of this paper is to determine to what extent the contemporaneous state of chivalry has influenced Chaucer's Knight in his literary endeavor. First I analyze the Knight's personality, which evinces his militant and nonconformist nature: as opposed to the majority of knights, Chaucer's Knight, in an attempt to uphold the ideal of chivalry, is engaged in religious campaigns, while he refrains from taking part in the Hundred Years War. To his eyes this is an immoral war among Christians which is mainly motivated by the lucrative desires of the so-called nobles.
\end{abstract}

From this critical position regarding the practice of chivalry, the Knight proceeds to relate a story inspired directly by Boccaccio's Tesedia. Nonetheless, the narrator intentionally maneuvers his source to present a grimmer view of chivalric conduct. All his interpolations with regard to Arcite and Palamon are geared to create a feeling of decadence, since they represent a perversion of the order of chivalry, as in the case of the breach of the bond of compagnonnage or in the omission of an attempt at reconciliation in the judicial combat. In addition, referring to Theseus, the Knight emphasizes the practical inefficacy of the aesthetic code of the order of chivalry that Theseus tries to implement.

Despite the pessimistic vision of the second estate suggested by this paper, the Knight's attitude must be framed in what Maurice Keen has called "chivalry's war against its own distorted image".

In The Canterbury Tales, the relation established between the pilgrims and their tales is usually complex; besides, as Elizabeth Salter (1962: 7) points out, "Chaucer's narrative techniques are very rarely concerned with fidelity to the nature and capabilities of the 
character who tells the tale". However, in the case of the Knight's Tale (c. 1380-87), the connection between the teller and his narration is manifest (Frost, 1960: 112-113). It is precisely my purpose in this paper to examine how the personal circumstances of the narrator directly affect his literary product. First, I will attempt to identify the individuality of the Knight by setting him in his historical context. Next, I will focus on the Knight's treatment of the chivalric actions contained in the tale.

I share the views expressed by Maurice Keen (1983: 47), who argues that Chaucer, in the case of both the Knight and the Parson has chosen figures "drawn very definitely from the contemporary scene whose lives indicate patterns of pious living that are not outmoded, but which too few, in Chaucer's opinion, made a sufficiently serious effort to follow". In that way, the Knight has concentrated his energies on fighting the infidel, which is the first duty of any knight. ${ }^{1}$ This military devotion is expounded thoroughly in the description of the character (16 lines) providing an inventory of the scant successes obtained in the fourteenth century by European chivalry over the heathen.

Although enrollment for crusades occurred in late fourteenth-century England, the participation in religious campaigns was insignificant if compared with other more lucrative military expeditions, such as the Hundred Years War. This kind of war had become a source of livelihood for a military class increasingly numerous, to the extent that certain members of the nobility "sold their services to the king in return for wages and promises of obtaining what were euphemistically known as the 'advantages' of war" (Allmand, 1988: 47). ${ }^{2}$

Nonetheless, our "verray, parfit gentil knyght" is imbued with the ideal of the order of chivalry. He repudiates those ignoble campaigns since he is conscious that "... falt q'il se soit armant / Non pour le lucre tant ne qant, / Mais pour droiture supporter" (John Gower, Mirour de l'Omme, 11. 24019-21) ["he must arm himself not for any lucre whatever but to uphold the right", Wilson, 1992: 314]. As a result of his moral integrity the Knight decides not to take part in the Hundred Years War (Sánchez Martí, forthcoming). Such a decision may have seemed blamable especially to the eyes of Chaucer's contemporary audience, who were immersed in the never-ending French war. ${ }^{3}$ These considerations confirm the validity of Keen's judgment quoted above.

Chaucer's election of a character with such a strong-willed profile is significant if we take into account the reality of chivalry in the last half of the fourteenth century: during these years the practicality of knighthood generates a feeling of decadence. This impression is based on "the belief that the ideals of conduct essential to chivalry became divorced from the realities of life during the fourteenth century" (Barnie, 1974: 57). This situation that affected chivalry was attested on both sides of the English Channel. John Gower (c. 13301408) in England denounces the profound crisis in the upholding of the chivalric ideals:

Car ce voit bien cil q'ore vit,

Chivalerie est trop perdue,

Verrai prouesce est abatue...

Car d'orguil ou du foldelit

Au jour present, sicomme l'en dist, 
Chivalerie est maintenue.

Mirour de l'Omme, 11. 23979-81, 23986-88

["but everyone alive nowadays can see that knighthood has been ruined; true prowess has been overcome... for (as I am told) knighthood is upheld nowadays by pride and wantonness", Wilson, 1992: 314]

On the other hand, Eustache Deschamps (c. 1346-1406) in France first refers to the past splendor of chivalry (Queux de Saint-Hilaire, 1880: 216):

Les jeunes gens poursuioient

Lances, bacinez portoient

Des anciens chevaliers...

Et leurs vertus esprouvoient

Huit ou dix ans tous entiers;

Puis chevaliers devenoient

Humbles, fors, appers, legiers.

Lay de Vaillance, 11. 55-57, 69-73

["The young men used to follow lancers, they used to wear the light helmets of the old knights... And they used to test their strengths for eight or ten whole years; then they became knights, humble, strong, skillful, agile", trans. mine]

Next, he describes in negative terms the contemporary situation of knighthood:

Leur jeunesce demener

Veulent et leur temps user

Es delis, manger et boire,

Mau paier, assez acroire,

Eulx polir com blanc yvoire,

Bien dormir et reposer...

Lay de Vaillance, $11.188-93$

["They want to spend their youth and use their time in pleasures, eating and drinking, paying badly and borrowing a lot, polishing themselves like white ivory, sleeping well and resting...", trans. mine]

To summarize, the narrator of the Knight's Tale is atypical and extraordinary if we keep in mind the moral crisis that his estate is suffering. His engagement with the ideal of the order of chivalry must have been visceral, and in the midst of an atmosphere of decadence his attitude seems to have been militant and relentless. Only the intensity of his identification with the second estate can explain his immediate narrative selection: when the Knight is chosen to begin the tale-telling game, without opportunity to reflect, "... he bigan with right a myrie cheere / His tale anon, and seyde as ye may heere" (I, 857-58); that is to say, the 
Knight, as the first teller, is not allowed time to decide a literary theme, and therefore, opts for the issue that appertains more directly to him. The election of a story of chivalric character proves the Knight's sensitivity and consciousness toward the circumstances of his estate, and stands as the case of greater connection between the narrator and the contents of his tale.

Having set the Knight in his historical context, I will now direct my attention to the chivalric conduct portrayed in the tale in order to contrast it with contemporary attitudes toward this behavior. In this sense, I will focus on the Knight's treatment of the representatives of knighthood in his tale; first, I will scrutinize Arcite's and Palamon's action, and next Theseus'.

Before applying this analysis, however, I would like to clarify an aspect that I consider relevant. The story chosen by the Knight is directly inspired by Boccaccio's Teseida (begun 1339), which is located in classical Greece. Our Knight, without modifying this backdrop, introduces a series of medieval elements that endow his narrative with greater contemporaneousness. The Knight's additions are concerned precisely with the chivalric aspects of the story and signify an adaptation to medieval practices (Robertson, 1915: 23839). Furthermore, both contemporary and modern readers have always been tempted to read the rivalry between Athens and Thebes as a mirror of the strife between England and France. $^{5}$

Strong evidence supporting that the Knight's Tale was actually read with contemporary implications is provided by John Lydgate (c. 1370-1449). He wrote a continuation to the Canterbury Tales starting with the return to London of the pilgrims. In their journey back, they recount the story of The Siege of Thebes (c. 1420-22), which renders entirely the Theban legend in English, establishing direct references to the Knight's Tale (cf. 11. 4501 ff.). In Lydgate's poem, the parallel with the Hundred Years War is made more noticeable, as is proven by the following lines (Erdman, 1911: 192):

But loue and pees / in hertys shal awake, And charitè /, both in length and brede, Of newë shal her bryghte beemys sprede Thorgh grace / only: in dyuers naciouns, Forto reforme / a-twixë Regyouns

Pees and quyet / concord and vnytè.

The Siege of Thebes, 11. 4698-4703

And such a connection is made even more explicit when he affirms: "To sende vs pes / her in this lyf present" (4713), with an obvious reference to the armed conflict with France.

I set out now to examine the chivalric attributes that our Knight confers on Arcite and Palamon. ${ }^{6}$ When Arcite and Palamon are found in the heap of corpses by Theseus' soldiers, they are first surprised because Arcite and Palamon wore the same heraldic device: "Bothe in oon armes" (I, 1012). This coincidence implies a very close relationship between the two knights; as Leach points out (1937), the use of the same device by two knights was one of 
the signs of compagnonnage or brotherhood by oath. Afterward, we confirm that the bond of compagnonnage actually exists between Arcite and Palamon when the latter refers the terms of their oath:

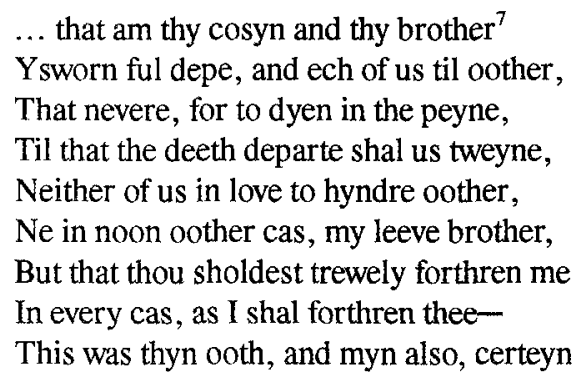

The institution of compagnonnage is a social ritual of a very long tradition which plays an important role in the foundations of chivalry (Gerould, 1906: 196). It was established by means of an oath, and implied obligations such as advice, vengeance for the death of the other, permission from the companion to marry someone, faithfulness to death, etc. This link is so strong that it is above everything else after God in the chivalric mind, and it is even more sacred than marriage.

However, this institution vanishes in the twelfth century, although it is kept alive in literature (Flach, 1891). The finest representation of brotherbood by oath in literature is conveyed by the medieval legend of Amis and Amiloun because "l'accomplissement de ces mêmes devoirs forme la trame événementielle du récit" (Legros, 1988: 120). Moreover, the literary references to comradeship are numerous in medieval English literature and Chaucer himself introduces this union again in the plot of the Shipman's Tale (VII, 41-42; see also Gerould, 1906: 197-200).

It is specific to Chaucer, however, that both in the Knight's and the Shipman's Tale he introduces this bond of compagnonnage between his characters to describe how they become corrupted and break their oaths; whereas, the other literary representations of compagnonnage are almost always exemplary of loyalty. Just after the exposition of the oath, Palamon accuses his sworn brother of "false Arcite" (I, 1145). From this moment onward, these two knights, once united by the sacred bond of compagnonnage, become mortal enemies, despite being aware of the dishonor involved: "For I defye the seurete and the bond / Which that thou seist that I have maad to thee" (I, 1604-5), says Arcite when they meet in the woods. The only justification they adduce for their behavior is found in Palamon's rhetorical question: "who shal yeve a lovere any lawe?" (I, 1164).

The condemnatory intention of this episode is patent: on the one hand, because the sworn brotherhood of Arcite and Palamon is an interpolation, since it is not mentioned in Boccaccio's Teseida; on the other, because the literary use of this medieval custom is contrary to the romantic tradition, since here it exemplifies an ignoble conduct. In my 
opinion, the Knight introduces this variation to present the discredit cast upon the second estate because of the degrading behavior of certain knights, even "of the blood roial".

Prior to analyzing the combat between the two knights, I would like to discuss an issue that, even though it may seem trivial, was controversial from a legal viewpoint: Palamon's flight from Theseus' prison (I, 1467-75). In one of the most influential treatises on the laws of War, Honoré Bonet's L'arbre des batailles (1386-89), complex casuistry is developed around the escape of a knight from another knight's prison (Ch. LV). The general principle states: "we must not do to another what we would not wish done to ourselves. And no man on earth would wish that his prisoner should break his arrest. Hence the prisoner must not break prison" (Coopland, 1949: 158). Next Bonet studies the particularities of specific cases in which the prisoner's flight is justified: "if he were kept in such close imprisonment that he was in danger of falling into languor, or mortal sickness, or any grievous ill of body" (op. cit., p. 159; cf. $K T, \mathrm{I}, 1337-46$ ), or "if his master refused to accept due and reasonable ransom" (ibid.; cf. $K T, 1,1024$ ). Palamon's action is therefore legal, although when he confesses his escape to Theseus he says "That hath thy prisoun broken wikkedly" (I, 1735, emphasis mine). Nevertheless, those two conditions that legitimate his flight are interpolated by Chaucer, since in Boccaccio's text we read that Theseus "...felli dentro al palagio abitare / e così in una camera tenere / faccendo lor servire a lor piacere" (II, 996-8; Limentani, 1964: 326) ["made them live in the palace and kept them in this way in a room where they were served at their pleasure", McCoy, 1974: 72]. Once more, the alteration occurs in the knightly demeanor of one of the knights, in this case Theseus', whose conduct will be discussed below in detail.

The next episode with clear chivalric implications is the fight between Arcite and Palamon. They are going to determine their case - who has more right to Emelye- by the ordeal of battle: "wilnest to darreyne hire by bataille" (I, 1609). In fact it is a judicial combat, whose existence can be explained "because of his [the medieval man's] inability to ascertain the truth behind two conflicting statements and because of his inherent belief in immanent justice and divine providence" (Mickel, 1985: 20); they believed that God would assure victory to the rightful side. This practice went against both Roman and canon law, and the Church prohibited it legally in 1215 , although it was already frowned at before this. However, the belief in it was deep-rooted among the population and judicial combats did not disappear immediately, and in fact they were common in fourteenth-century England.

Judicial combats followed a defined ritual, as Pfeffer (1885) expounds; our text, however, does not present all the phases of the ritual, but it has several: the accusation (Palamon says: "Arcite, false traytour wikke, / Now artow hent, that lovest my lady so", I, 1580-81), a challenge (Palamon implicitly suggests a combat: "I wol be deed, or elles thou shalt dye. / Thou shalt nat love my lady Emelye", I, 1587-88, which Arcite interprets properly: "wilnest to darreyne hire by bataille", I, 1609), an acceptance (Arcite takes the challenge: "Have heer my trouthe; tomorwe I wol nat faille", I, 1610), the election of place and time ("... at tyme and place yset", I, 1635), an inspection of equipment ("And bringen harneys right ynough for thee; / And ches the beste, and leef the worste for me", I, 1613- 
14), the investment of arms ("Everich of hem heelp for to armen oother", I, 1651), and the fight proper (I, 1653-60).

Nonetheless, there are two important parts of the ritual which are omitted. First, the absence of a judge or lord that presides over the combat. Bonet's treatise is very detailed in this respect:

Suppose appellant and appealed have agreed to fight without enclosure, and without the presence of the lord. By argument of the written law it would appear that they may do this, but I do not believe that they may ... Hence, the field must be enclosed, the lord or his deputy must be in charge, and no man may enter (Ch. CXVI; Coopland, 1949: 200).

One may argue that the original source renders the combat in such a way. On the other hand, considering the level of formality combats attained in this period, the narrator's aim at creating a sensation of contemporaneousness, and considering that the narrator is a knight himself, I cannot but identify certain intentionality in this omission.

The other component absent from this combat is an attempt at reconciliation. The day of the fight both knights, driven by hatred and animosity, act without desire for finding a rational solution to their disagreement, and the Knight implicitly refers their negation to reconciliation: "Ther nas no good day, ne no saluying, / But streight, withouten word or rehersyng..." (I, 1649-50). This is again a considerable departure from Boccaccio's version, in which Arcite, with the identity of Pentheus, attempts at dissuading Palemon of the mistake of battling (cf. I, 45-54; Limentani, 1964: 341-344), and tries it again just before starting the combat: "ma, così amando, volentier vorrei / con teco pace, e presto a ciò sarei" (V, 63 ${ }^{7-8}$; Limentani, 1964: 403) ["Yet loving the way I do, I would willingly make peace with you, and I would be ready for that", McCoy, 1974: 130]. As in the previous examples, the Knight's rendition presents modifications from its source in details relevant to the world of chivalry; these departures, however, generate a harsher representation of the knightly estate.

I set out now to examine Theseus' conduct, whose characterization is rather complex and difficult to define. In 1950 (repr. 1959) Charles Muscatine formulated an interpretation both of the tale and of Theseus' function that would become standard. In Muscatine's opinion, Theseus is presented as "the representative of Fate on earth" and of "the principle of order" (p.73), and he is the embodiment of the ideal of chivalry. This reading has been adopted grosso modo by all Chaucerian criticism with some exceptions that argue that "the Tale depicts its human world in a more critical light than Muscatine's view ... will allow" (Underwood, 1959: 455; cf. also Webb, 1947; Aers, 1980; Jones, 1985: 194-212).

I will not assume the thesis of any of the critics cited, but rather focus on the text without forgetting contextual elements. However, I would like to start making a consideration about the literary perception of Theseus in the fourteenth century. Kurt Olsson (1987: 131) affirms that "the Knight casts Theseus as an ideal, magnanimous ruler"; conversely, Theseus is very often quoted as an example of willful ruler. The most noteworthy case is provided by Boccaccio in his collection of notable personages, which includes improper deeds by Theseus and concludes by saying: "ne ..., dum Theseum redarguimus, iure eius 
in infortunium meriti incurramus" (Ricci, 1983: 64) ["While we disapprove of Theseus, we should not deserve to fall justly in his misfortune", trans. mine]. Chaucer himself includes references to Theseus in two other poems, in which he portrays "How fals eke was he Theseus" (House of Fame, 11. 405 ff., and see also The Legend of Good Women, 11. 18862227). Therefore, if the Knight truly intends to depict Theseus as the representative of the ideal of chivalry, his choice seems contradictory, although I will follow the Knight's Tale to assess this impression.

Theseus' presentation is reminiscent of the Knight's description in the General Prologue: "...gretter was ther noon under the sonne, / Ful many a riche contree hadde he wonne; / What with his wysdom and his chivalrie" (I, 863-65) ${ }^{8} \mathrm{Next}$, the military side of Theseus is commented upon: "He conquered al the regne of Femenye" (I, 866), and then, compelled by the widows' supplication, he attacks Thebes, which was governed in "tyrannie" (I, 941) by Creon; first, Theseus fights in "pleyn bataille" $(I, 988)^{9}$ against Creon, and, after having defeated him, he "rente adoun bothe wall and sparre and rafter" $(I, 990)$ "and dide with al the contree as hym leste" (I, 1004).

This phase of "conquerour", from the point of view of knighthood, apparently offers a rather ideal portrait. First, he has fulfilled the fourth duty of a knight, according to Llull's codification: "to helpe and ayde them that al wepynge requyre of the knyghtes ayde and mercy / and that in them haue their hope" (Byles, 1926: 40, Caxton's trans.); he has also proved that "he was a trewe knyght" (I, 959) with all his victories.

However, some critics have isolated a series of details that they understand as a departure from the ideal (see Jones, 1985: 172-174). When Theseus is intercepted by the women in his glorious return, he instinctively reacts with certain arrogance: "Have ye so greet envye / Of myn honour, that thus compleyne and crye?" (I, 907-8). This vice is criticized by Llull: "Pryde is a vyce of Inequalyte / or to be inegal to other and not lyke / For a proud man wylle haue no pere / ne egall to hym / but loueth better to be allone not lyke ony other" (Byles, 1926: 104, Caxton's trans.). Besides, he adopts a more positive attitude when he finds out that these women "hat been a duchesse or a queene" (I, 923), which compels him to take action (I, 956). However, the value of this criticism must be relativized, since the two aspects commented occur in Teseida.

Conversely, the devastating action of Theseus' army over Thebes and the pillage he commands are additions to Boccaccio's text. Webb criticizes Theseus for his violent gestures, yet I believe that Chaucer's purpose is rather different: these interpolations should be understood as elements of military realism (cf. Aers, 1980: 176; Robertson, 1915: 228; Barnie, 1974: 10). Furthermore, it is rather improbable that these innovations might be interpreted negatively, since they are uttered by a character so used to similar situations. In any case, this divergence performs a coherent literary function: by means of his destructive force, Theseus imposes chaos in the city of Thebes, over which he will have to implement order as a "governour".

The first course of action taken by Theseus as a ruler is the imprisonment of Arcite and Palamon without possibility of ransom. Here he shows his judicial competence as a good ruler: "a king or prince should have the virtue of justice, for according to law it is the proper 
attribute of a king to do justice" (Coopland, 1949: 212). This question, however, has caused dissension among the critics of the Knight's Tale. For Robertson $(1915: 212)$, the ruling out of ransom suggests the "unmercenary character of Theseus", whereas for Terry Jones (1985: 197) it is another instance of "the ruthlessness of the tyrant". If we consult Bonet's treatise, the casuistry is varied, although he acknowledges that a "decretal says that it is unlawful for a man to demand money from his prisoner" (Coopland, 1949: 152). In addition, Jehan Froissart (c. 1337-after 1404) refers how Bertrand of Guesclin, the constable of France, had been captured by the army of the Black Prince at Nájera in 1367, but fearing that, if released, he would renew the war in Spain, "demora encores prisonniers messires Bertrans de Claiekin au prince et à monsigneur Jehan Chandos, et ne pooit venir à raençon, ne à finance, dont moult desplaisoit au roy Henri" (Lettenhove, 1967, vol. 7: 245) ["sir Bertram of Guesclin was still prisoner with the prince and with sir John Chandos and could not come to his ransom nor finance, the which was sore displeasant to king Henry", Bourchier, 1913: 184]. This would be sufficient to legitimate the incarceration of the heirs of the Theban royalty without option to ransom. Textual support may be added to this historical evidence. In Teseida we read that "Così da lui Arcita e Palemone / dannati furo ad etterna prigione" (II, 98 ${ }^{7-8}$; Limentani, 1964: 326) ["And thus were Arcites and Palaemon condemned to eternal imprisonment by Theseus", McCoy, 1974: 72], and the Knight's Tale preserves the same sense: "... to dwellen in prisoun / Perpetuelly ..." (102324). Yet it is adapted historically to the medieval context on which the story is projected, and a detail is introduced "he nolde no ransoun". Therefore, Theseus' conduct in this respect should not be qualified of ignoble.

From this point onward Theseus generates the sensation that he is directing Arcite's and Palamon's destiny as a lord and "trewe juge":

And forthy I yow putte in this degree,
That ech of yow shal have his destynee
As hym is shape, and herkneth in what wyse...
My wyl is this, for plat conclusioun
Withouten any repplicacioun.

I, 1841-43, 1845-46

Theseus formulates these words, in a clearly judicial tone, after interrupting the chaotic and unchivalric combat between the two cousins, and suggests explicitly his intention of organizing the events that affect immediately the lives of the two knights. Yet this interventionist will had already proved insufficient when Theseus decreed their unconditional life sentence, since both knights were free again.

His purpose now is to direct the natural energy of Arcite and Palamon into the chivalric procedures by means of organizing a tournament, which Theseus presides over like "a god in trone", and which apparently should settle the dispute between Arcite and Palamon. Even though this episode appears in Teseid $a$, the splendid description of the arrangements and the preparations of arms and armor (I, 2495-2512) are additions by Chaucer which integrate 
his project of contemporization. Moreover, Theseus' chivalric vocation is strengthened by providing an activity suitable for knights.

However, Theseus' designs have crumbled once more. At the end of the tournament, Theseus decrees that "Arcite of Thebes shal have Emelie" (I, 2658), but the fateful intervention of the "furie" solicited by Saturn prevented his plan. As Blake (1973: 8) explains, "though Theseus appears to offer an ordering and resolving force, it is clear by the end that the force he wields is not effective to those purposes". Arcite's death provides the only moment in the tale in which, after the repeated failure of his ordering will, Theseus loses confidence: "No man myghte gladen Theseus, / Savynge his olde fader Egeus, / That knew this worldes transmutacioun" (I, 2837-9). Nevertheless, Theseus continues implementing his executive impulse and "he took conclusioun" (I, 2857) concerning Arcite's funeral and designates Emelye's marriage:

\footnotetext{
"Suster," quod he, "this is my fulle assent, ...

That gentil Palamon, youre owene knyght, ...

That ye shul of youre grace upon hym rewe,

And taken hym for housbonde and for lord."
}

I, 3075, 3077, 3080-81

To summarize, although the Knight depicts Theseus as a character devoted to the code of chivalry, he also criticizes the actual ineffectuality of the order Theseus creates. In relation to these organizational activities Blake (1973: 16) states: "all this is orderly, ceremonious, admirable. But it is an aesthetic solution, not a practical one", an opinion to which I subscribe.

In conclusion, the critical representation of chivalry in the Knight's Tale accords with both the mentality of the narrator and his context. On the one hand, by means of the conflict between Arcite and Palamon, the Knight censures the limited observance of knightly values by some knights. On the other hand, the practical inefficacy that reveals the implementation of a certain aesthetical understanding of the chivalric code, even by a character who embodies these principles, demands a reform of the order of chivalry. However, despite the pessimistic vision of the second estate suggested in this paper, I must say that all this criticism needs some undermining, since "chivalry always appeared to its thoughtful practitioners ... to stand in need of reform" (Kaeuper and Kennedy, 1996: 48; cf. Brewer, 1998: 42). In this way, the critical elements that I have identified in the tale should be framed in what Keen (1984: 237) has called "chivalry's war against its own distorted image".

\section{Notes}

1. In John Gower's words, "Ecclesie prima debet defendere iura" (Vox Clamantis, V, 5). All quotations from Gower are from Macaulay (1899-1902). 
2. As Geoffroi de Charny states in c. 1352, "ce doit l'en mettre en ce metier plus son cuer et s'entente a l'onnour, qui tous temps dure, que a proffit et gaing que l'en peut perdre en un seule heure", (Kaeuper and Kennedy, 1996: 98). In John Barnie's opinion (1974: 95-96), "the association of chivalry with material gain may indicate an area of moral insensibility on the part of the second estate, but this should be seen as one of the limitations of chivalry itself rather than as a new factor indicating the decline of chivalric idealism in the fourteenth century".

3. Terry Jones utilizes the Knight's objection to the Hundred Years War to reaffirm his thesis, and concludes that "at a period of crisis for the English nation, he has failed to serve his own country with spectacular single-mindedness and has ranged all over the known world in search of fat pickings" (1985: 101).

4. All quotations from Chaucer are from Benson et al. (1987).

5. The line that has inspired the most this allegorical interpretation is "To have with certein contrees alliaunce" (I, 2973). For a study of the relations of the tale with its historical milieu, see and Olson (1979).

6. Despite the different characterization of the two knights (Wetherbee, 1995: 220), for the purpose of this paper I will approach them together.

7. The use of the word "brother" gives linguistic evidence of the nature of their bond. It is used reiteratively: I, $1161,1181,1184$, etc.

8. Cf. I, 45, 48, and 68. In fact, the relative parallel between the Knight and Theseus has been pointed out by several critics. Blake (1973: 18) finds in common between Theseus and the Knight the fact that the latter is of highest degree among the pilgrims, and also behaves like an arbiter when he patches up the quarrel between the Pardoner and the Host. Fyler (1979: 139) argues that "both have strong military interests, and an intense delight in the details of pageantry and tournaments. Theseus's care in setting up the tournament and building the arena is matched by the Knight's zest in describing his preparations". However, these similarities between two knights are almost inevitable.

9. This line echoes the "mortal batailles" (I, 61) of the Knight.

\section{Works Cited}

Aers, David (1980): "Imagination, Order and Ideology: The Knight's Tale". In Chaucer, Langland and the Creative Imagination. London: Routledge, 174-195.

Allmand, Christopher (1988): The Hundred Years War: England and France at War c. 1300-c. 1450. Cambridge: Cambridge UP.

Barnie, John (1974): War in Medieval English Society. Social Values in the Hundred Years War 1337-99. Ithaca: Cornell UP.

Benson, Larry D. et al. (eds.) (1987): The Riverside Chaucer. Boston: Houghton Mifflin. Blake, Kathleen A.(1973): "Order and the Noble Life in Chaucer's Knight's Tale". Modern Language Quaterly 34: 3-19.

Bourchier, John, Lord Berners (trans.) (1913): The Chronicles of Froissart. London: MacMillan. Brewer, Derek (1998): A New Introduction to Chaucer, 2nd edn. London: Longman.

Byles, T. P. (ed.) (1926): The Book of the Ordre of Chyvalry, translated and printed by William Caxton from a French version of Ramón Lull's "Le Libre del Orde de Cauayleria" together with Adam Loutfut's Scottish transcript., EETS, os 168. London: Oxford UP. 
Coopland, G. W. (trans.) (1949): The Tree of Battles of Honoré Bonet. Cambridge, Mass.: Harvard UP.

Erdman, Axel (ed.) (1911): Lydgate's Siege of Thebes, EETS, es 108. London: Kegan Paul.

Flach, J. (1891): "Le compagnonnage dans les chansons de geste". Études romanes dédiées à Gaston Paris, Paris: Bouillon, 141-180.

Frost, William (1960): "An Interpretation of Chaucer's Knight's Tale". In R. J. Schoeck and J.

Taylor, eds., Chaucer Criticism: The Canterbury Tales. Notre Dame: University of Notre

Dame Press, 98-116.

Fyler, John (1979): Chaucer and Ovid. New Haven: Yale UP.

Gerould, Gordon H. (1906): "Social and Historical Reminiscences in the Middle English Athelston". Englische Studien 36: 193-208.

Herz, Judith Scherer (1964): "Chaucer's Elegiac Knight". Criticism 6: 212-224.

Jones, Terry (1985): Chaucer's Knight: The Portrait of a Medieval Mercenary. New York:

Methuen.

Kaeuper, Richard W. and Elspeth Kennedy (eds.) (1996): The Book of Chivalry of Geoffroi de Charny. Philadelphia: University of Philadelphia Press.

Keen, Maurice (1983): "Chaucer's Knight, the English Aristocracy and the Crusade". In V.

J. Scattergood and J. W. Sherborne, eds., English Court Culture in the Later Middle

Ages. New York: St. Martin's Press, 45-61.

Keen, Maurice (1984): Chivalry. New Haven: Yale UP.

Leach, MacEdward (ed.) (1937): Amis and Amiloun, EETS os 203. London: Oxford UP.

Legros, Huguette (1986): "Quand les jugements de Dieu deviennent artifices littéraires ou la

profanité impunie d'une poétique". La justice au Moyen Age: Sanction ou impunité.

Senefiance 16: 197-212.

- (1988): "Ami et Amile: Compagnonnage épique et/ou amitié spirituelle". Bien dire et bien aprandre. Revue de Médiévistique 6: 113-129.

Lettenhove, Kervyn de (ed.) (1867-1877; repr. 1967): Oeuvres de Froissart. Osnabrück:

Biblio-Verlag.

Limentani, Alberto (1964): Teseida delle Nozze di Emilia. In Tutte le opere di Giovanni Boccaccio, vol. 2. Milan: Mondadori.

Macaulay, G. C. (ed.) (1899-1902): The Complete Works of John Gower. Oxford: Clarendon Press.

McCoy, Bernadette Marie (trans.) (1974): The Book of Theseus. Teseida delle Nozze d'Emilia by Giovanni Boccaccio. New York: Medieval Text Association.

Manly, John Matthews (1907): "A Knight There Was". Transactions and Proceedings of the American Philological Association 38: 89-107.

Mann, Jill (1973): Chaucer and Medieval Estates Satire: The Literature of Social Classes and the General Prologue to the Canterbury Tales. Cambridge: Cambridge UP.

Mickel, Emanuel (1985): "The question of guilt in Ami et Amile". Romania 36: 19-35.

Mitchell, Charles (1964): "The Worthiness of Chaucer's Knight". Modern Language Quaterly 25: 66-75.

Muscatine, Charles (1959): "Form, texture and meaning in Chaucer's Knight's Tale". In Edward Wagenknecht, ed., Chaucer: Modern Essays in Criticism. New York: Oxford UP, 60-82.

Olson, Paul A. (1979): "Chaucer's Epic Statement and the Political Milieu of the Late 
Fourteenth Century". Mediaevalia 5: 61-87.

Olsson, Kurt (1987): "Securitas and Chaucer's Knight". Studies in the Age of Chaucer 9: 123-153.

Pfeffer, M. (1885): "Die Formalitäten des gottesgerichtlichen Zwei kamps in der altfranzösischen Epik". Zeitschrift für Romanische Philologie 9: 1-75.

Queux de Saint-Hilaire, Le Marquis de (ed.) (1880): CEuvres Complètes de Eustache Deschamps, SATF. Paris: Firmin Didot, vol. 2.

Ricci, Pier Giorgio and Vittorio Zaccaria (eds.) (1983): De Casibus Vironum Illustrium. In Tutte le opere di Giovanni Boccaccio, vol. 9. Milan: Mondadori.

Robertson, Stuart (1915): "Elements of Realism in the 'Knight's Tale'". Journal of English and Germanic Philology 14: 226-255.

Salter, Elizabeth (1962): Chaucer: The Knight's Tale and the Clerk's Tale. London: Arnold.

Sánchez Martí, Jordi (forthcoming): "Chaucer's Knight and the Hundred Years War". SELIM. Journal of the Spanish Society for Medieval English Literature 7.

Underwood, Dale (1959): "The First of the Canterbury Tales". English Literary History 26: 455-469.

Webb, H. J. (1947): "A Reinterpretation of Chaucer's Theseus". Review of English Studies 3: 289-296.

Wetherbee, Winthrop (1995): "Chivalry under Siege in Ricardian Romance". In I. A. Corfis and M. Wolfe, eds, The Medieval City under Siege. Rochester: Boydell Press, 207-223.

Wilson, William Burton (trans.) (1992): John Gower. Mirour de l'Omme (The Mirror of Mankind). East Lansing: Colleagues Press. 